\title{
The making of Monstrous Breaches: An ethical global visual narrative
}

\begin{tabular}{c|c} 
Judith Lovell & Kathleen Kemarre Wallace \\
$\begin{array}{c}\text { Northern Institute, Charles Darwin University } \\
\text { Judith.Lovell@cdu.edu.au }\end{array}$ & Northern Institute, Charles Darwin University \\
\hline
\end{tabular}

Keywords: ethics, artistry, intercultural, global, visual, narrative, monsters

\section{An introduction}

Kathleen Wallace is an Eastern Arrernte custodian and artist with a 45-plus year career as a cultural expert and teacher. Her paintings are widely collected and when considered as one extensive body of work represent her homelands and the relationships of Eastern Arrernte to the sociocultural traditions and systems within those homelands. Judy Lovell has been a collaborator with Wallace for 15 years; she is an Anglo-Australian academic and artist with a background in arts therapy and research. Judy's interest in Bajan and Caribbean folklore stems from the links in her ancestry to African and British descendants from Barbados.

Describing the making of Monstrous Breaches here gives us an opportunity to reveal some of the elements at work when our artistry, narrative and research occur in intercultural contexts that depend on our adoption of ethical processes as artist researchers who are communicating from very different cultures and heritages. Though they are so often left unspoken and remain unseen, it is important to uncover and explore these processes that underpin the concept of our ethic in this applied research and artistry - if we wish to engage well at this interface of cultures and styles and traditions with the wider global intercultural imagination.

The creative provenances of Monstrous Breaches include the style of its representation as well as the sometimes-thorny issues of the references within it to Indigenous and other iconographies and narratives. We discuss our collaboration as a form of provenance that is dependent on an ethical engagement with practical wisdom and applied while drawing, carving and printing this image to its completion. We believe this provenance is essential to the imagery, designed to challenge and take away the power of today's monsters through illuminating their contemporaneity and the Monstrous Breaches that affect our globally connected worlds.

This narrative is about the making of Monstrous Breaches. Stories and depictions of monsters have been told and shown in every culture, with the intent that, as artistry does, these provide ways to interpret those things in our lives which may be beyond what we know, beyond our experience, and yet are within the grasp of our imaginations. Some monsters are beyond what we know, but monstrous things still happen. Many of us have had some experience of the monstrous in our lives, of monstrous things we can't control, but which breach our worlds, laws and beliefs, and whose conduct is unethical. 


\section{The background}

The references for the making of Monstrous Breaches are the monsters with whom we, the authors, are most familiar: those of the Eastern Arrernte and other central Australian Aboriginal homelands, and those with Bajan and European roots. Here in central Australia, Arrernte stories have been told by Aboriginal people for generations (Turner \& MacDonald, 2010; Wallace \& Lovell, 2009). Many of them have been the subject of Wallace's work - especially her public storytelling, teaching and painting - over the span of her career. They are also the stories that informed her education and assisted in her survival as a child in the homelands, growing up with grandparents who lived entirely on country and away from the missions and other settlements until Wallace was 12 years old. Only then did her European education begin, and the intercultural, global and educative elements of her work begin to develop

Further influencing Monstrous Breaches are the folkloric Bajan monsters of the Caribbean, particularly those that prey on the 'unbecoming', people whose fate is cast in both physical and spiritual dispossession from their ancestral homelands (Clarke, 1999, p. 37). These monsters relay something of the manipulation of the vulnerable, and the savagery of the powerful - the colonisers' brutality, and the global diasporas of the aftermath. These are monsters who prey on insecurity, on the uncertainty of becoming, an uncertainty born into generations without ancestral paths to follow, generations who were enslaved in a country far from their ancestral beings, demoted in the monstrous breach that was slavery and indenture, and the economic exploitation which remains. Folklore of these monsters and stories of those monstrous breaches are taught and told in the hope that we never forget, never allow, and never repeat.

And yet then there are monstrous breaches today, which are global and, while never associated with one country or one people or one place, have the power to breach the natural world. Capable of powerful and monstrous havoc, such global monsters arrive without foretelling, without tradition, without face or name. Personal monsters abound too, capable of producing the monstrous breaches in the social fabric of our worlds that we see and fear and live with every day, and yet we have no stories to prepare ourselves to do battle with these monsters either. We have no folklores or Arrernte laws governing the damage wrought when today's monsters take over. So how do we name them, call them out, diminish them? How do we know them to deny or defeat them?

We made this big picture, not to give power to monsters but to imagine within one scene the unseen and unspoken nature of today's monsters, making them present, so that in seeing and naming them they are diminished, reduced, overcome, recognised, called out, or put aside. We created this imagery because we wanted to interpret the foundation through which others can see meaning even without a common spoken language. This image is for all who want to tell their own story of monsters. It is intended to be given meaning by you, the audience, and in the process of engaging your imagination, we are all making tangible a greater intercultural and global imagination - one that defeats monsters, and reduces monstrous breaches. 
The artwork

Figure 1. Monstrous Breaches, 2016 (2/6).

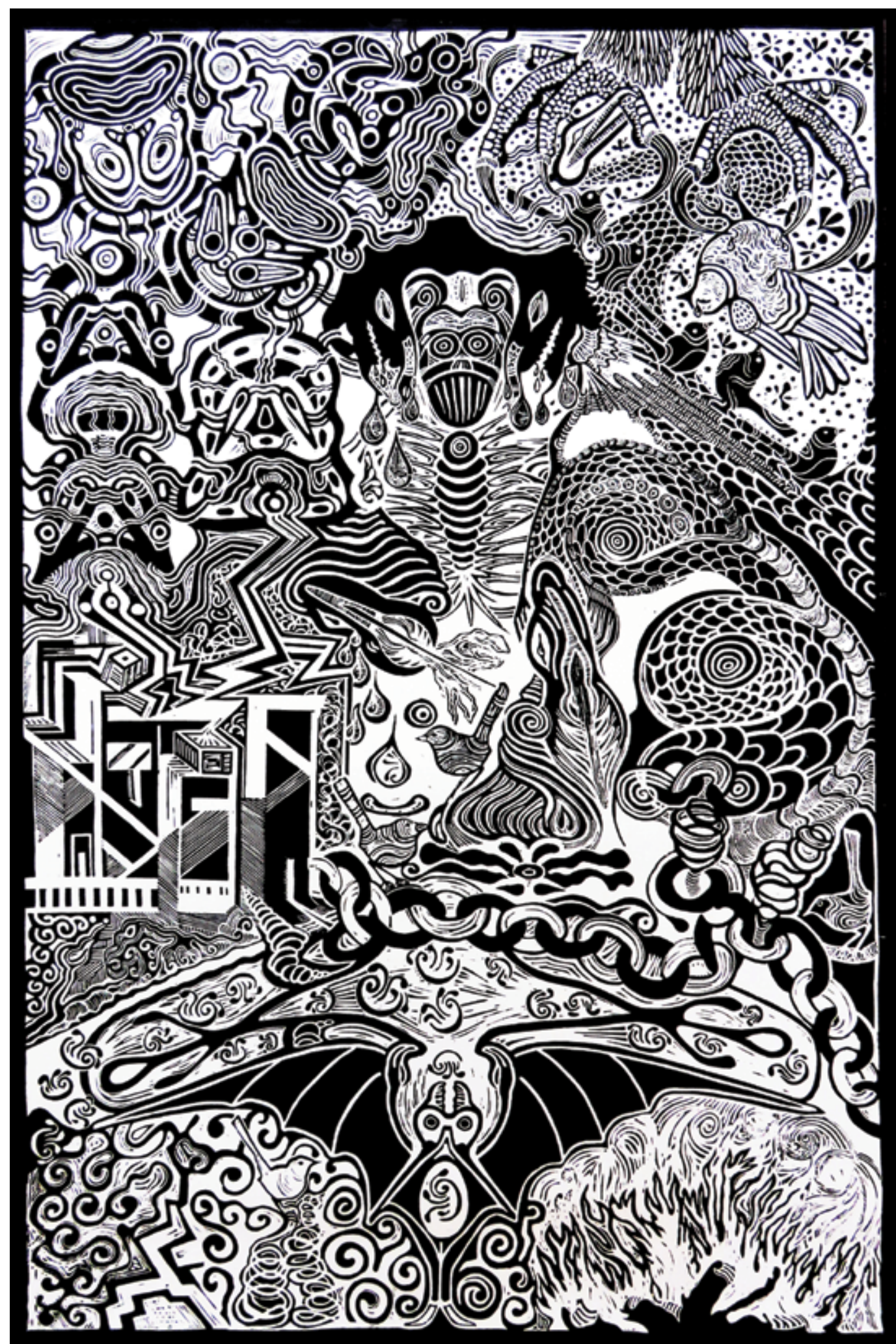

Source: Kathleen Wallace and Judith Lovell. Linocut limited edition monoprint (1.75m x 1.1m) Graphics Ink on Fabriano paper, roller and barren printing method. 
Monstrous Breaches, (the image) is a large black and white lino monoprint $(1.75 \mathrm{~m} \times 1.1 \mathrm{~m})$ that we, the researchers, have worked on for a year, between 2015 and 2016. This work is important for its process, its provenance, and for what its content means to you, as well as to us.

\section{The imagery}

The large black and white image depicts several monsters coalescing over land, through air and across water. The monsters don't have explicit stories but instead are inspired by those we perceive in everyday life and find in the cultural roots and stories of the Arrernte and Bajan societies we refer to. The "everyday-ness" of our monsters also refers to the ordinary kinds of things that can become monstrous in people's lives today, and how monstrous influences can control some people, perhaps for generations to come, while only affecting others briefly. We thought about how the monsters of today are similar to and different than the monsters Wallace grew up with - especially the Arrentye (monsters) stories from Eastern Arrernte homelands, and those in Bajan (Clarke, 1999) and European folklore, such as Lovell was taught about in childhood.

In this picture, monsters take many forms. As the bat lingers at the base of the picture we remember the anger and violence of bat tribes fighting each other at Arturte-akerte, a place in the Simpson desert near Wallace's grandfathers' homelands. In that story, the male bats hacked off and tore at one another's flesh, burning the chunks as the piles mounded up around them, forming hills of molten stone. The victorious bat men stood atop these hills, chopping their enemies as they flew at them. As the flesh chunks mounded up, they burned so hot they become molten, smooth, round stones. Rock piles like that are still mounded into hills in the sand dunes behind Merne-anthenge, an eastern range of hills on the edge of the Simpson Desert (Wallace \& Lovell, 2009, pp.145-149).

A third of the way from the top, in the centre of the picture, is that malevolent and mischievous two-headed monster. That was made while we were thinking about the Bajan La Diablesse who is always out to take innocence away, luring those who follow her, drunkenly, to the edge and then over the precipice and into the abyss (Clarke, 1999, p.37-38). We drew our two-headed monster as one that drags people - claws extended, pulling and drawing them in - alluring, beckoning, seducing - crooning and soothing. Those are the traits of another Arrentye too, a monster with long fingernails, who may sing out in Arrernte, 'apetyaye, apetyaye' 'come here, come here' as she draws to her the children who are lurking alone near waterholes, and the curious, the defiant - those ones who won't listen to their elders' warning. Or are too curious, wanting to see Arrentye. Afterwards, the marks from her fingernails can be seen on them, scratched deep into the cheeks of her drowned child victim. (Wallace \& Lovell, 2009, p. 72). This double-faced monster may not look as dominant as the bat, but you might never escape if she sinks fangs into your blood stream, poisoning your body and spirit. The Soucouyant of Caribbean folklore is sometimes called the vampire monster, and she too wreaks havoc with flesh, using fire and fangs. Stripping herself of her skin she becomes a fiery ball, and slips in through the cracks and crevices to the bedside of her victim, whose blood she then sucks out (Clarke, 1999, p. 37).

We live in central Australia and so we always have an awareness of this country. From it we took the contrast between the natural landscape and an urban landscape, which appears at first so powerful and fast, an enticing, inviting novelty (middle right). But in that hard-edged place, we can become disembodied. Unforgiving of natural forms, steel chain links are wrought by fire, forging the chains that bind and weigh down, restrict and encircle. These are symbols of enslavement as well as of unbroken links, bonds. It has been told that after La Diablesse passes by some hear clanking chains. Here, chains hang from the tail of the many-headed 
serpent, suspended over the shadow-people and linked to the angled hard corners of the urban blocky city, where light is reflected harshly from flat-edged surfaces. Above the city float the masks of the disembodied, and the whirling serpent (middle centre and left) who sucks away the spirit, with its rasping hot air, ensnared by chains, and with slicing claws, it too holds a dead innocent (the bird top left).

Above the bat, the two human figures aren't monsters, they are shadow people, barely there. We all have shadows, spirits, good or bad influences. Like the birds in this picture, some are harder to see or hear, to name or know, as shadows that come over us, and the little shapes around the shadow figures - like bacteria - maybe good or bad; they can be either, or both. They are in water, in air, and inside us - keeping us healthy or making us sick. It depends on the mix and strength, it depends on the source and whether we can discern wisdom from monstrosity, whether we can see the monstrous and call it out.

\section{The purposes}

Looking back at the picture after making it, Wallace reflects on why she was drawn to it:

What draws me to look at this picture is that city [middle, right]. It's bringing people in to where there is something happening...But when they are there they start the drinking. See their reflections [masks, top right]? They have changed. Look different. Now they become part - a part of that monster [grog]. First, they just go to see what's happening and then from drinking, they become aggressive. Fighting. Just like those bats at Arturte. They don't see how they changed from grog. Looking at themselves, they can't see how monstrous they become.

In any of these monstrous states, a person is incomplete, losing their identity, or having never found it, they live with the loss of self, and with no will to complete (Clarke, 1999, p. 38). Perhaps feeling powerful, the aggressive one demands, the spiteful one challenges and takes, the novel one subjugates, and the alluring one manipulates. Then, having become overwhelmingly monstrous, looks for someone else, something else, to blame. The monster that is in our own reflection is hidden so well that we do not see what we are, or what we may never become. But that is, in some part at least, the job of stories and artistry: to reflect what we don't see and give voice to the consummately disguised, like the ingratiate monsters that lurk at the edges of our imagination, or those that overcome us.

See: there isn't one story here - there are many. Stories and ideas and themes, these are our images, fed by the stories of the homelands, of apmere Uyetye-akerte and Therirrerte-akerte, as well as the stories of other Bajan folklore that we know from books. Regardless of the stories that we are familiar with, it's the different stories that the audience make for themselves from these images that matter most, and those are why we made Monstrous Breaches. The stories that the audience make will fill the space between Monstrous Breaches and their own experience - and in doing this, can articulate other, previously unspoken, invisible, or unfamiliar monsters. The audience confirms how these monsters, by their existence and actions, can cause monstrous breaches of the law and the land, ruining the human and non-human worlds we know, diminishing the fundamental things which govern our existence. Wallace reflects about how the stories of monsters ensured her survival and that of other generations of Arrernte:

When I was told monster stories, Arrentye is something it's real frightening. We were always told not to do the things that Arrentye tells us to do: but some kids always want to know what Arrentye is. And they don't listen to their parents or 
grandparents they just want to know and then they end up being killed or being drawn to do these things Arrentye wants. There were so many Arrentye stories we were told when I grew up...I had to learn not to do many things but now days we have kids doing things and they don't listen to us - they just do things themselves and they become part of these monstrous things we see today; today those Arrentye(s) look like grog and gunja, ice and pills - there's so many new things that people do now, that we never even knew about.

That's why we are trying to help young kids today teaching about not to do these things; because Arrentye is taking them away, and telling them wrong ways. Maybe there is more Arrentye(s) now because there are lots of monstrous things happening...

In life today, kids don't have the same struggles as we had in earlier time...they can go to the shops for food, there are shops everywhere and they sell everything; there are houses for shelter, water in taps...In the old days, there was only the natural world and living in that natural world people had to take care all the time; we only had ourselves and there was danger everywhere. To survive, we had to know what to do, where to go, we had to listen to the old people; we had to ignore the allure of Arrentye to survive.

Some kids are curious though - they want to see what's over there - see what Arrentye is, and they see it in reflection - in gunja, in grog. Arrentye can take over a person - grog can take over - grog is Arrentye - it takes over who a person is, how they are to other people, it damages their mind, their spirit and body, their relationships...that is Arrentye. That is like that Arrentye who would draw kids into the water and drown them, or attack other people, kill them in the camp site.

\section{Our learning}

While making Monstrous Breaches we learnt one another's cultural ways of understanding and we also learnt about one another's artistry and how we engage our own and each other's imaginations. We discovered how we each use design, and how we like to depict things within a setting with references to landscape, how those things are arranged when our shared drawing surface is treated as an Arrernte landscape - a landscape in which ancestors had an ordered way of knowing and teaching stories about safety, survival and law. Monstrous Breaches is an image formed by the aesthetic gaze of one whose eyes are turned to meet the aesthetic gaze of another, in a learned Arrernte world that has its own systems of organisation and aesthetics.

We know that monstrous breaches are not specific to one culture or one group of people, but are a force of human and nature and more-than-human worlds. Nonetheless, this picture was made in this setting: in Alice Springs, which is in Arrernte country. A healthy Arrernte framework was put in place first to make working on this project together a safe thing to do on these homelands. So, as we designed Monstrous Breaches we started with the bat at one end and the hands at the other, then we put down the lines of skin groups and ceremony grounds underneath. That framework respects the healthy Arrernte system of country, people and the relationships between them. This has always been the way Wallace paints, with the designs and relationships of country and people as the first layer on her canvas, which also shows the rest of us her sovereignty, responsibility and stewardship. We put those foundations there first to make sure this was a safe and respectful thing to do here, together. 
That composition gave us a balance in the image too, which we gradually changed. First, we had the bat and the two-headed monster - with the pulling and tension between them. Then we had other elements - water, fire, smoke, the city, all corresponding. Stronger symbols emerged after all those elements were placed and as we overlayed the monsters onto the compositional shapes of Arrernte organisation - human, more-than-human, law and country. Then the tension, the struggle, the fighting - monsters arranged in opposition to each other, as well as to us and to you, the audience. Tension and anger, fire and water, aggressor and seductress, reflections in water, smoke from fire, chains and torment - carved as light and dark. Wallace says of the way monsters overtake our lives today:

This can happen to everyone, to anyone, it's not just Aboriginal people; it can happen to anybody.

But underneath all this mayhem is the ordered Arrernte life world, with a formal arrangement that respects the kinship of people, country and spirit, sources of strength and wisdom just as much as these depictions reflect contemporary monsters of our everyday world. Although no longer visible to the audience of this image, the ordered design of Arrernte relationship systems is the under-painted layer upon which these monstrous images are made visible. Weaving cultural, artistic, narrative and other sources into a global imagery is a task fraught with potential mishap, and dependant on robust collaboration, authentic communication and respect for those systems of knowledge, such as the Arrernte have, that have framed the human ecology of these societies and these landscapes over thousands of years.

\section{Our intent}

Using artistry increases the opportunity to communicate at a depth not available without a comprehensive vocabulary and a shared oral language, and as there are many spoken languages in the world we cannot share the depths of knowledge and understanding only with words. The visual holds the potential for rich communication with audience and between artists in situations where we are without commensurate depths of linguistic understanding. There are two levels at which we intended this image to 'work' across different cultures: between the artists and between the imagery and the audiences.

Just as with linguistic capability to interpret and respond to the cultural and social inferences that another language encapsulates, applying artistry across artistic traditions in collaboration requires skills that are honed in the familiarity and the give-and-take of shared studio practices - exchanging techniques and ideas, giving response and critique, but respecting one another's aesthetic ideas and motivations, and acknowledging that traditions, while never static, are different; our aesthetics are derived differently. Working like this involved trust, and a shared commitment to learning and research. There is no short cut to this practice; no set of rules or list of skills that can be developed outside of such relationships, only the applied principles of artistry and practical wisdom.

In keeping with the intention of the piece to act as a cypher or conduit for audience interaction, right from the start we wanted Monstrous Breaches to be available to people who want to reuse the imagery in their own forms of art. We invite people to appropriate in the spirit of ongoing collaboration to name and defeat the monsters of fear, incommensurability, and othering that breach intercultural and other collaborative practice and in doing so, thwart the making of shared knowledge, global imagination and mutual respect.

This picture might help people express how they feel, what is in their lives, how they feel drawn or pushed, bullied or frightened - it might help children learn that monstrous things can seem 
so attractive, but this can also make them part of the monster as they lose themselves. That's the main thing about this picture - it's to offer something that other people can use to express their story, make their own narrative. In ending, we'd like to ask you to remember: How did you learn about monsters?

\section{Acknowledgement}

We would like to acknowledge Dr Christine Black, a Kombumerri/Munaljahlai woman from south-east Queensland, for her encouragement and support of the development of this work, and Dr Al Strangeways for her encouragement of its production. 


\section{References}

Clarke, L. (1999). Obeahing the space. Caribbean Quarterly, vol. 45, no. 2-3, pp. 36-40. Kingston: University of the West Indies.

Turner, M. K., \& MacDonald, B. (2010). Iwenhe tyerrtye: What is means to be an Aboriginal person. Alice Springs: IAD Press.

Wallace, K., \& Lovell, J. (2009). Listen deeply: Let these stories in. Alice Springs: IAD Press. 